\title{
Correction to: Corruption in China: What Shapes Social Attitudes Toward It?
}

\author{
Zuzana Fungacova ${ }^{1} \cdot$ Ilari Määttä2 $\cdot$ Laurent Weill $^{3,4}$
}

Published online: 12 April 2019

(c) Association for Comparative Economic Studies 2019

\section{Correction to: Comp Econ Stud https://doi.org/10.1057/s41294-018-00083-8}

Due to an unfortunate oversight the author name Ilari Määtta has been misspelt. It should be read Ilari Määttä.

The original article has been corrected.

Publisher's Note Springer Nature remains neutral with regard to jurisdictional claims in published maps and institutional affiliations.

The original article can be found online at https://doi.org/10.1057/s41294-018-00083-8.

Laurent Weill

laurent.weill@unistra.fr

1 Bank of Finland, Helsinki, Finland

2 Institute of Economics, Technology University of Braunschweig, Brunswick, Germany

3 EM Strasbourg Business School, University of Strasbourg, Strasbourg, France

4 Moscow State Institute of International Relations (MGIMO University), Moscow, Russia 